NBER WORKING PAPER SERIES

\title{
THE IMPACT OF CHINA ON THE EXPORTS OF OTHER ASIAN COUNTRIES
}

\author{
Barry Eichengreen \\ Yeongseop Rhee \\ Hui Tong \\ Working Paper 10768 \\ http://www.nber.org/papers/w10768
NATIONAL BUREAU OF ECONOMIC RESEARCH
1050 Massachusetts Avenue
Cambridge, MA 02138
September 2004

The views expressed herein are those of the author(s) and not necessarily those of the National Bureau of Economic Research.

(C2004 by Barry Eichengreen, Yeongseop Rhee, and Hui Tong. All rights reserved. Short sections of text, not to exceed two paragraphs, may be quoted without explicit permission provided that full credit, including (C) notice, is given to the source. 
The Impact of China on the Exports of Other Asian Countries

Barry Eichengreen, Yeongseop Rhee, and Hui Tong

NBER Working Paper No. 10768

September 2004

JEL No. E5, F4

\begin{abstract}
We analyze the impact of China's growth on the exports of other Asian countries. Our innovation is to distinguish the increase in China's demand for imports from its increased penetration of export markets. Using the gravity model, we disaggregate among commodity types and account for the endogeneity of Chinese exports. We confirm the tendency for China's exports to crowd out the exports of other Asian countries. But this effect is felt mainly in markets for consumer goods and hence by less-developed Asian countries, not in markets for capital goods or by the more advanced Asian economies for which machinery and equipment are a significant fraction of exports. At the same time, there has been a strong tendency for a rapidly growing China to suck in imports from its Asian neighbors. But this effect is mainly felt in markets for capital goods, where China's income elasticity of import demand is highest, and thus by the more advanced Asian economies. Hence, more and less developed Asian countries are being affected very differently by China's rise.

Barry Eichengreen

Department of Economics

University of California

549 Evans Hall 3880

Berkeley, CA 94720-3880

and NBER

eichengr@econ.berkeley.edu

Yeongseop Rhee

Sookmyung University

Seoul

South Korea

Hui Tong

Bank of England

Threadneedle Street

London EC2R 8AH

England
\end{abstract}




\section{The Impact of China on the Exports of Other Asian Countries \\ Barry Eichengreen, Yeongseop Rhee and Hui Tong ${ }^{1}$ September 2004}

\section{Introduction}

China's integration into the world economy is one of the most important developments affecting the structure and evolution of the global system at the dawn of the $21^{\text {st }}$ century. Over the last 20 years, China has grown at a rate of nearly 10 per cent per annum, driven primarily by the expansion of the modern, industrial, export-oriented sector. With some 20 million Chinese workers moving from rural underemployment to the modern sector annually, the impact is akin to adding another middle-sized industrial economy to the world economy each year. And with between 200 million and 300 million workers still to be reallocated from rural underemployment, this is not simply a one-time shock but an ongoing process that should continue for a decade and more. ${ }^{2}$

China is now the sixth largest economy in the world when its output is measured at market exchange rates; at purchasing power parities it is of course larger still. ${ }^{3}$ It is the world's fourth largest trader. Reflecting its growth strategy, its exports have grown even faster than its economy, at rates in excess of 20 per cent per annum. As a result China's share of world trade has risen from less than 1 per cent two decades ago to 6 per cent

\footnotetext{
${ }^{1}$ University of California at Berkeley, Sookmyung University, and Bank of England, respectively. An earlier draft of this paper was presented at the KIEP/Claremont conference on East Asian regionalism, Seoul, 26-27 August 2004. We thank Charles Adams and Andrew Rose for helpful comments. This paper represents the views of the authors and should not be thought to represent those of the Bank of England. ${ }^{2}$ Of course, there are some who warn of the existence of serious challenges, such as the condition of the banking system and the state enterprises, that may interrupt the growth process, as well as constraints like relatively low levels of human capital that may pose even more persistent problems. We do not address these questions in the present paper.

${ }^{3}$ Insofar as the focus of this discussion is China's impact on other economies and the latter is felt primarily through channels like trade, market rather than purchasing power parity exchange rates are the appropriate basis for comparison (a point made by IMF 2004).
} 
today. Its market share in Japan (that is, the share of Japanese imports originating in China) more than tripled between 1990 and 2002, rising from 5.1 per cent to 18.3 per cent. The same is true of its market share in the United States, which rose from 3.2 per cent in 1990 to 11.1 per cent in 2002 . The same is again true, albeit starting from a lower base, of the European Union, where the comparable figures are 2.0 and 7.5 per cent. ${ }^{4}$

The structure of China's exports has been changing as well, away from the clothing, footwear, other light manufactures and fuels that dominated its trade in the 1980s and early 1990s, toward office machinery, telecommunications, furniture and industrial supplies in the late 1990s and automated data processing equipment and consumer electronics in recent years. Along with the growth of Chinese exports has come the rapid growth of Chinese imports. What was once a chronic trade surplus has recently become a deficit, reflecting China's growing demand for primary commodities (such as crude oil and copper), intermediate inputs (components for electronic products and other consumer durable goods), and capital goods (in consequence of the economy's high investment rate).

The effects of these trends are likely to be felt especially intensely by China's Asian neighbors. Geographical proximity, shared borders, linguistic commonalities, and the existence of extensive networks of overseas Chinese are among the reasons to expect large amounts of trade between China and the rest of Asia. In some cases, similarities in stages of economic development, factor abundance, technological capability, and production costs mean that other Asian economies will compete head to head with China in third markets. Thus, China's emergence may intensify the competitive pressure felt by other Asian economies, slow the growth of their exports, and challenge the sustainability

\footnotetext{
${ }^{4}$ These figures are adjusted for intra-EU trade.
} 
of high growth more generally. In other cases, different stages of economic development, technological capability and comparative advantage may mean that China's exports and other Asian countries' exports are complements rather than substitutes. To the extent that China's exports are still dominated by consumer goods, the country does not compete directly in third markets with advanced Asian economies like Japan and South Korea that export machinery and equipment. In addition, China's modern, export-oriented manufacturing sector relies on imported raw materials, energy, components, and capital equipment. Thus, the faster the country's exports grow, the faster will grow its imports of materials, components and equipment, thereby stimulating rather than slowing the export growth of its neighbors. At some level it is obvious that all of these factors are at work, to a different extent in different countries. The most that can be said at this level of abstraction is that the impact of China's export growth on the exports of other Asian economies is unclear.

How China's emergence is affecting the export competitiveness of the country's neighbors has important implications at the national, regional and global levels. Most obviously, the impact of China's exports has implications for national development trajectories, in Asia and elsewhere. If the addition each year of another medium sized emerging market to the global economy drives down the world market prices of laborintensive manufactures, this will heighten the incentive for other countries to move up the technological ladder into the production of more technologically-intensive, less laborintensive exports in order to better insulate themselves from Chinese competition. In order to do so, they will presumably want to invest even more in human capital. In 
contrast, countries that produce raw materials and capital goods utilized intensively in Chinese manufacturing may wish to specialize further in these areas.

At the regional level, China's emergence suggests that any regional free trade arrangement or effort to more closely coordinate monetary and financial policies will not be attractive if it does not involve what will eventually be the region's largest economy. This fact already finds reflection in policy, for example in the Chiang Mai initiative to provide swap lines and credits for financially-embattled economies, which is a project of ASEAN+3 (ASEAN plus China, Japan, and South Korea).

Globally, the impact of China's exports on the exports of other Asian countries has implications for whether we should expect a revaluation of the yuan to lead to a general revaluation of Asian currencies and to thereby help to redress the problem of global imbalances. One frequently heard argument is that if China revalues, moderating the competitive pressure felt by other Asian economies, those other Asian economies will be able to revalue as well, and the general realignment of Asian currencies against the U.S. dollar will help to narrow the U.S. current account deficit and relieve the competitive pressure felt by Europe without causing major disruptions to the world economy. But if China's exports are positively correlated with the exports of its Asian neighbors, insofar as the main impact of China's export growth is to stimulate that country's own demand for imports of raw materials, components, and capital equipment from elsewhere in the region, then a revaluation of the RMB which slows the growth of China's own exports may work to reduce the exports of the neighbors, depressing rather than boosting their own growth and creating pressure for depreciation rather than appreciation elsewhere in the region. Thus, the general revaluation of Asian currencies 
seen by some observers as a solution to the problem of global imbalances may not in fact follow from a slowing of Chinese growth due to a tightening of domestic credit or from a yuan revaluation.

These are the questions motivating the analysis in this paper of the impact of China's exports on the exports of its Asian neighbors. In contrast to most previous efforts to address this issue, we estimate the impacts in question using econometric methods, rather than deriving them from a simulation model where the results flow from the assumptions implicit in the calibration of key parameters. We distinguish the impact of China's growth on its own imports from other Asian countries, on the one hand, from its impact on the exports of other Asian countries to third markets, on the other. We distinguish the impact of China's growth on other Asian countries' exports of capital goods, intermediates, and consumption goods. And we distinguish the impact of Chinese competition in industrial- and developing-country markets.

Our results are striking. We find that the crowding out of other Asian countries' exports to third markets resulting from the growth of China's exports is limited to consumer goods, at least at this stage. In contrast, the increase in other Asian countries' exports to China is most elastic in the case of capital goods. This implies that the effect of Chinese growth is negative for low-income Asian countries that export mainly consumer goods and feel the brunt of Chinese competition in third markets, but positive for high-income Asian countries that export mainly capital goods and benefit from China's voracious appetite for imported machinery and equipment. 


\section{Previous Studies}

There have been a few previous analyses of these questions. The study with the strongest similarities to our own is Ahearne, Fernald, Loungani and Schindler (2003). The authors use a panel of annual data spanning the period 1981-2001 for four NIEs (Korea, Singapore, Taiwan, and Hong Kong) and four (additional) ASEAN members (Indonesia, Malaysia, Philippines and Thailand), considering the impact of China's exports on the exports of these neighboring countries. They regress the growth of these countries' exports on the growth of foreign incomes and the change in the country's real exchange rate, and then add China's real export growth as an additional regressor to these export equations. ${ }^{5}$ While the coefficient on Chinese exports tends to be positive, suggesting complementarities between its exports and those of its Asian neighbors, the effect in question rarely approaches statistical significance at standard confidence levels. On this basis the authors conclude that there is "little evidence that increases in China's exports reduce the exports of other emerging Asian economies. Indeed, it appears that China's exports and exports of the other countries are positively correlated."

The question has also been addressed in the context of China's WTO accession. China's accession to the WTO is modeled as a liberalization of its trade regime that increases its propensity to import and export. Thus, Ianchovichina and Walmsley (2001) calibrate and simulate a multi-country, multi-sector model of international trade, and find that China's WTO access, while increasing the country's own exports, reduces the exports of Vietnam, the Philippines, Thailand and Indonesia and Malaysia (due mainly to the negative impact on their textile and apparel sales). They find that WTO accession

\footnotetext{
${ }^{5}$ Country fixed effects are also included in the regressions, as are a lagged dependent variable and lagged independent variables in some cases.

${ }^{6}$ Ahearne et al. (2003), p.21.
} 
has a positive impact on the exports of Japan and the NIEs (Hong Kong, South Korea, Singapore and Taiwan), due mainly to the increase in their exports to China of high quality textile and electronics inputs (along with miscellaneous exports of processing industries). As they summarize their results, "Japan and the newly industrialized economies in East Asia will also benefit from China's accession to the WTO...As important suppliers of materials to China, these countries will observe an improvement in their terms of trade and returns to capital.” In both Japan and the NIEs, the projected increases in production are driven mainly by expansion in exports to China. On the other hand, their simulations suggest a decline in exports (mainly of textiles and apparel) and a reduction in GDP relative to baseline levels in East Asia's developing countries.

Similarly, Yang and Vines (2000) simulate a multi-sector, multi-country model with differentiated products as a way of analyzing the impact of China's growth on exports from other Asian countries, finding that the exports of the ASEAN countries drop slightly while those of Japan and the NIEs both rise. These overall effects are the sum of positive effects on exports to China itself and negative effects on exports to third markets, which differ in size depending on the Asian exporter concerned.

Yet another simulation is that of IMF (2004), which uses a computable general equilibrium model designed to capture the geographical and sectoral structure of trade flows. This analysis points to a small negative impact on the exports and output of all regions. In terms of output, this negative effect (measured as the percentage deviation from the values obtaining in the slow-Chinese-growth baseline) is largest for the Middle East and North Africa and smallest for the advanced economies. The ASEAN economies experience a somewhat larger than average impact, while the NIEs and South Asian 
economies show a somewhat smaller than average impact. The precise effects vary by sector and country. For example, countries that rely heavily on exports of textiles and clothing, labor-intensive manufactures in which China also has a comparative advantage tend to experience particularly large negative effects.

The limitations of the literature will now be apparent. The results of simulation studies are dependent on how the models in question are calibrated, which tends to beg the question at hand. Econometric studies have not yielded precise estimates of the key effects, leading investigators either to draw inferences from coefficients that are not significantly different from zero or to suggest on the basis of their failure to identify a significant effect that one does not exist. This gives us more than enough motivation to reconsider the question.

\section{Data and Methodology}

Our data on trade flows are from the IMF's Direction of Trade Statistics. They provide us with bilateral merchandise trade between 180 IMF trading entities through 2002. ${ }^{7}$ CIF imports are recorded in millions of U.S. dollars. We deflate imports by the U.S. CPI for all urban consumers. ${ }^{8}$ Real GDP and GDP per capita (in constant 1995 U.S. dollars) are obtained from the World Bank's World Development Indicators. Other country-specific variables, such as land area and language, are from Rose (2002). ${ }^{9}$

The framework for our analysis is the familiar workhorse of the empirical international trade literature, the gravity model. We consider bilateral flows between the

\footnotetext{
${ }^{7}$ Below we also use the United Nations trade data base, whose country coverage is somewhat more limited (149 versus 180 countries) but which permits us to disaggregate capital goods, intermediates and consumer goods.

8 1982-1984=100; from http://www.bls.gov/data/home.htm.

${ }^{9}$ The distance measure, on which we comment further below, is from Rose's website as well.
} 
13 Asian exporting countries and all 180 importing countries. ${ }^{10}$ Using a matrix of bilateral trade flows, we regress the log imports of country i from country j (say, of Denmark from South Korea) on the log GDPs of the two countries, the log per capita GDPs of the two countries, the distance between them, and the other now-standard gravity model arguments (combined land area, land lockedness, number of islands, common language, common colonizer, whether the countries in question were ever in a colonial relationship). Our innovation is to include a measure of China's exports to the same market (in the case of the present example, Denmark). In addition, we model separately China's imports from other Asian economies using this same framework. ${ }^{11}$

It is important to recognize the potential endogeneity of China's exports. Unobserved factors (for example, an improvement in consumer sentiment worldwide) that increase South Korea's exports to Denmark will also in general increase China's exports to Denmark, creating a correlation between the error term and the key explanatory variable. The standard treatment for this type of problem is instrumental variables, the difficulty being the paucity of plausible instruments that is the bane of empirical macroeconomics.

Fortunately, in the present context the gravity model suggests instruments that are both plausibly exogenous and strongly correlated with Chinese exports. The obvious

\footnotetext{
${ }^{10}$ With provision for observations dropped due to missing variables. When no trade is recorded between a pair of countries, it is not clear how to treat this observation. Conventional practice in the gravity model literature (followed here) has been to simply drop these observations. An argument can be made that this is a source of truncation bias. Fortunately, studies like Eichengreen and Irwin (1995) that have used Tobit and similar methods to adjust for the possibility of truncation tend to find that the impact on the estimated coefficients is minimal.

${ }^{11}$ Unfortunately, it is not possible to include country-pair fixed effects, which authors like Anderson and Marcouiller (2002) suggest might be quite important in practice, since we are already using a country-pair specific variable, namely distance. Below we follow Anderson and Marcouiller's suggestion for how to address this problem, namely to add country-specific institutional variables.
} 
instrument, in other words, is the distance between China and the country that is the destination of its exports.

In addition, the gravity model suggests including China's GDP as an instrument in the first-stage equation. While this variable, like distance, is strongly correlated with China's exports, questions can be raised about its exogeneity. But the dependent variable in the first stage regression is China's exports to a particular market, Denmark for example, not its aggregate exports. While there are compelling reasons for thinking that China's model of export-led growth involves causality running from export growth to GDP in addition to the other way around, it is less plausible that China's aggregate GDP is significantly affected by its exports to Denmark. In practice, the results for the equations we discuss are essentially the same when we limit the instrument set to distance, although the coefficient estimates are slightly less precise.

\section{Basic Regression Results}

We start with the equations for the impact of China's exports on the exports of other Asian countries. These cover the period 1990-2002. ${ }^{12}$ Recall that we include here observations for all bilateral trade flows between Asian countries and their trading partners (South Korea's exports to the United States, South Korea's exports to Denmark, etc.), excluding of course the observations for China's exports and imports, which are treated separately in Section 9 below.

\footnotetext{
${ }^{12}$ While we also have data for earlier years, prior to 1990 China was significantly less integrated into the world economy, making it unlikely that the information content of these earlier data will shed useful light on current concerns. Below we discuss how the results change when we limit the analysis to an even shorter period.
} 
Panel a of Table 1 shows the results of estimating the model with the constraint that the basic gravity-model coefficients are the same for all importing and exporting countries. The bottom of the table (panel b) shows the results of the first stage regression for China's exports, which is useful for gauging goodness of fit and will come in handy for counterfactual simulations. Note that standard econometric methodology dictates including in the first stage not just China's GDP and the distance from China to the third market but also the other exogenous variables from the second stage.

The gravity model fits the data well. Exports rise with the GDP and GDP per capita of the importing and exporting countries. They fall with distance and with the combined land mass of the trade partners (geographically large countries tending to do more internal trade and less international trade, other things equal). Land-locked countries and countries spread across multiple islands trade less, while countries presently or previously in a colonial relationship, that share a common border, and that share a common language trade more. All of these effects except for common land border are significantly different from zero at the 95 per cent confidence level.

The variable of particular interest, the fitted value or exogenous component of Chinese exports to the same market, enters with a negative coefficient of -0.18 and a t statistic of 7.38 (column 1 of panel a) when the full set of instruments is used. This tells us that, other things equal, a 10 per cent increase in Chinese exports to a particular market results in a 1.8 per cent decline in the sales of the competing Asian country in that market. The effect differs significantly from zero at standard confidence levels. 
Column 2 shows what happens when we drop China's GDP from the instrument set. ${ }^{13}$ The coefficient on China's exports is still negative (-0.22), although somewhat less precisely estimated (with a t statistic of 6.94). It is also interesting to contrast the instrumental-variables results in columns 1 and 2 with the OLS results in column 3. Clearly, using distance from China as an instrument makes an important difference. In column 3 (which we include only for comparison's sake), the coefficient on China's exports is positive.

\section{Sensitivity Tests}

One reason to worry about the robustness of these results is structural change, a phrase that is frequently uttered in the same breath as China. Given rapid changes in the composition and direction of Chinese exports, the third country effects could be different in earlier and later years. Our first set of sensitivity analyses, in Table 2, therefore replicates the preceding analyses for the second half of the sample period (1997-2002).

The change in results is plausible. The crowding out effect is now larger ( 0.33 instead of 0.18). Still, these changes are still not large enough to overturn our other results. ${ }^{14}$

An additional reason for caution is that our main instrumental variable, the distance from China to third-country export markets, is not time varying. In effect, we are trying to answer a time series question (how China's growth is affecting the exports of its neighbors) mainly by exploiting the cross-section variation in the data. The appropriate treatment for this problem is to add time-varying instruments. For example,

\footnotetext{
${ }^{13}$ While we are skeptical, for reasons explained above, that Chinese exports to an individual national market (as distinct from total Chinese exports) have a first-order impact on Chinese GDP, the results using the more limited set of instruments are nonetheless useful for gauging the robustness of our findings. ${ }^{14}$ Specifically, the results of our simulation exercises in Section 9 below are not significantly different when we base our calculations on these alternative coefficients for the second half of the sample period.
} 
Anderson and Marcouiller (2002) suggest that institutional variables such as corruption and imperfect contract enforcement have a significant impact on the propensity to trade and should be included in gravity model estimates. Intuitively, these variables capture the tendency for insecurity and country risk to act as a hidden tax on trade. While measures of them display persistence, they are far from constant over time. In our context, the implication is that changes in China's country risk (as a proxy for the ease and reliability of trading with the country) can be added as a time-varying instrument to the first-stage regression. This argument implies also adding country risk for the two trade partners to the second stage regression. ${ }^{15}$

We obtain our measure of country risk from the International Country Risk Guide (ICRG), which seeks to assess political, economic and financial risk. Here we focus on its measure of political risk, which seeks to capture bureaucracy quality, corruption, democratic accountability, ethnic tensions, external conflict, government stability, internal conflict, investment profile, law and order, military in politics, religious tensions, and socioeconomic conditions. The political risk index runs from 0 to 100 , with higher values implying lower risk. ${ }^{16}$

Table 3a shows what happens when we add this variable to the first and second stages. The country risk variables enter as expected. In addition, our previous findings are little changed. Most importantly, the coefficient on China's exports, at -0.16 , is very similar to before. The one instance where the results are noticeably affected is when we use the limited set of instruments, dropping China's GDP. There, the coefficient on

\footnotetext{
${ }^{15}$ This has the further advantage of adding variables that are close substitutes for country fixed effects.

16 Between 1990 to 2002, the period covered here, the index for China varies from 56 to 75 . For additional details on the index, see http://www.prsgroup.com/commonhtml/ methods.html\#_ International_Country_Risk.
} 
Chinese exports goes to -0.05 . China's country risk has been declining, while its GNP has been rising. The correlation of the two variables thus accounts for the change in results. ${ }^{17}$

We now ask whether these results are affected by disaggregating trade. Initially, we disaggregate along two dimensions. We distinguish industrial- and developingcountry importers. And we distinguish different Asian exporters.

Previously we assumed that China's exports crowd out the exports of each Asian exporter in each third-country market to the same extent. In columns 1 through 4 of Table 4 we relax this assumption, estimating the same equation separately for industrialand developing-country importers. ${ }^{18}$ The results do not suggest significant differences in the extent of crowding out of Asian countries' exports to the two sets of markets.

In columns 5-6 we allow for different effects of Chinese competition on different Asian exporters. The effects now range from -0.46 for Bangladesh to -0.16 for Malaysia. While it is possible to tell stories about these patterns (for example, that the most crowding out is suffered by countries like Bangladesh that are most dependent on exports of textiles and other consumer goods in which Chinese competition is particularly intense), we would not attach too much weight to them, since the equations including the entire vector of interaction terms suffer from multicolinearity. ${ }^{19}$ Here is one place where different specifications yield rather different coefficient estimates, which is a caution against overinterpreting these results.

\footnotetext{
${ }^{17}$ When including country risk in the regressions that follow, we therefore utilize the full instrument set so as not to attribute to this variable the effects of rising Chinese incomes.

${ }^{18}$ Here and in what follows, we continue to include the country-risk measure added in the previous section on the grounds that estimates with time-varying instruments are more reliable.

${ }^{19}$ The standard test for multicolinearity, the variance inflation factor (VIF) test, exhibits a statistic close to 30 , which is evidence of multicolinearity. While it is unusual to find multicolinearity when many of the coefficients in question are seemingly so precisely estimated (when they have $t$ statistics well above 2), these large $t$ statistics reflect our large sample.
} 
Finally, in columns 7-8 we allow for different elasticities for imports by industrial and developing countries and for different Asian exporters to both types of markets. ${ }^{20}$ Again, we observe considerable variation in the extent of crowding out across exporting countries and import markets. Again, however, it is hard to know how much weight to place on these results - or how to interpret them - given the extent of multicolinearity. ${ }^{21}$

\section{Distinguishing Capital Goods, Intermediates, and Consumer Goods}

Much of our intuition derives from the idea that China's growth has different implications for exporters of capital goods, intermediate goods, and consumer goods. If this is what is driving our results, then we should examine this issue directly. Unfortunately, IMF data do not disaggregate trade in this way. In this section we therefore utilize the United Nations' disaggregated trade data base, which allows us to do so. The cost is somewhat less complete geographical coverage. We therefore first replicated our previous analysis using the UN data. Reassuringly, the results are little changed. For example, in the benchmark estimates of Table 1, the coefficient on China's exports in the second stage falls only from -0.18 to -0.17 when the full instrument set is used and from -0.23 to -0.16 when we use the limited set of instruments. ${ }^{22}$ The UN data mainly miss out a number of small island countries and poor African economies.

Evidently, their trade is not sufficiently important to noticeably modify our results when it is dropped.

\footnotetext{
${ }^{20}$ Now in order to obtain the total effect one must add the coefficient on the interaction of imports from China ("fitimchina") with the individual Asian country dummy (for cases where the import market is a developing country) to the three-way interaction of fiited imports from China, the Asian exporter dummy, and an industrial country dummy (for cases where the import market is an industrial country).

${ }^{21}$ Despite the respectable $t$ statistics on a number of the interaction terms, the VIF test again produces a statistic close to 30 .

${ }^{22}$ As usual, the standard gravity-model variables continue to perform nicely. The estimates in Table 4 are similarly little changed.
} 
We divided commodity exports into capital goods, consumer goods, and intermediates (and other products) in the following way. The UN data are classified on the basis of the second revision of the Standard International Trade Classification (SITC). Capital goods include machinery and transport equipment (a subset of SITC 7). Consumption goods include food (SITC 0), beverages and tobacco (SITC 1), miscellaneous manufactured articles (SITC 8), television and radio receivers (7.6.1, 7.6.2, and 7.6.3), passenger motor vehicles and cycles (7.8.1 and 7.8.5), and medicinal and pharmaceutical products (5.4). All the remaining goods (SITC 2,3,4,5,6 and 9) are classified as intermediates.

Here we focus on the results for all importers and exporters combined (in order to avoid the multicolinearity problem identified above). Table 5 thus reports three equations, one for exports of capital goods, one for exports of intermediate goods, and one for exports of consumer goods. As before, we now include the distance from China to the third country export market, China's GDP, and China's country risk in the first stage regression.

The results are quite interesting. The coefficients for China's exports are small and statistically indistinguishable from zero in the equations for capital goods and intermediates. (The respective t statistics are 0.8 and 0.4.) In contrast, there is a large negative coefficient $(-0.28)$ in the equation for consumer goods with a t statistic of 8.1. From an econometric point of view, this is consistent with our earlier results for total trade; our earlier coefficient of -0.17 is effectively a weighted average of the large negative coefficient for consumer goods exports and the small coefficients for the other two categories of exports. 


\section{China's Imports}

The last set of regressions needed to construct the counterfactual is for the impact of Chinese growth on Chinese imports. Once more we base our estimates on the gravity model framework (where the volume of Chinese imports depends on GDP and GDP per capita in China and the exporting country). One problem with applying the gravity model in this context is that the distance variable - calculated here as the distance between country geographic centers - enters insignificantly or with the wrong (positive) sign. A little reflection reveals why: distance from other Asian countries to China's geographic center is not a meaningful measure of economic distance, given that much of the country's trade-relevant economic activity is concentrated not at its center but along the coast. Bangladesh is 11 per cent closer than Vietnam to China's center, but Vietnam is much closer to the Pearl River Delta, where much of China's export-relevant economic activity takes place. Differences in the distance between China's geographic center and, say, Bangkok versus Copenhagen do in fact tell us something about the relative (transportation and information) costs of exporting from China to Thailand versus Denmark. This is why distance is a powerful instrument in the first-stage regressions using the global sample, as reported above. But in the context of China's imports from its Asian neighbors, the distance between geographic centers works less well. Hence, in the equations for China's imports from other Asian economies, we drop the distance variable.

The results are in Table 6. The elasticity of Chinese imports with respect to Chinese GDP is on the order of one when the equation is estimated over the entire period 
1990-2002; this is more or less true for every Asian exporter. But when the sample is limited to the second half of the period (1997-2002), we see considerably larger Chinese import elasticities of demand, in particular for high-income Asian exporters of capital goods and components (Japan, Korea), for Asian exporters of energy and raw materials (such as Indonesia) and, interestingly, for India. In contrast, this elasticity is lowest for low-income, relatively resource-poor Asian countries like Bangladesh, Sri Lanka and Cambodia.

Table 7 reports separate equations for Chinese imports of capital goods, intermediate goods and consumer goods. The income elasticities of demand for capital goods, intermediates and consumer goods are all positive, as expected. But the income elasticity for capital goods is especially large, in excess of two. This is consistent with the oft-heard observation that China's growth is good for suppliers of machinery and equipment.

\section{Counterfactuals}

We now use the preceding estimates to ask how each country's exports (to China, to third countries, and as a whole) are affected by a ten per cent increase in Chinese income. Note that this avoids the "fallacy of composition" problem in previous studies where the comparative-statics experiment is an increase in Chinese exports. These studies have been criticized (e.g. by Mayer 2003) for ignoring the fact that an increase in Chinese exports presumably reflects and results in an increase in Chinese incomes that also stimulates Chinese imports. Asking how an increase in China's exports will affect the global export market shares of other countries without recognizing that the underlying 
increase in Chinese incomes will also translate into an increase in that country's demands for imports from its trading partners neglects an important part of the question.

Our estimates are not subject to this problem, since the counterfactual here is an increase in Chinese GDP. We use our gravity model estimates to derive the implications of that GDP growth for China's exports and the impact they have in turn on the exports of its Asian neighbors to markets other than China. The first stage regressions tell us that a 10 per cent increase in Chinese GDP is associated with an 11.7 per cent increase in China's own exports; according to the disaggregated trade data, this breaks down into a 23.2 per cent increase in its exports of capital goods, an 11.5 per cent increase in its exports of consumer goods, and a 10.9 per cent increase in its exports of intermediates. We then combine those results with our estimates of how China's export growth affects the third-market exports of its neighbors and how its income growth affects it imports from other Asian countries. ${ }^{23}$

We use the parameters estimated over the full period 1990-2002 with the trade data disaggregated into capital goods, intermediate goods, and consumer goods. ${ }^{24}$ For China's own import demands, we use the different income elasticities for different exporting countries in Table 7. For other countries' import demands, we use the estimates based on the assumption that these parameters are the same for all exporters and importers, excepting of course China itself (as in Table 5). ${ }^{25}$

\footnotetext{
${ }^{23}$ To be sure, this is not the end of the story. Presumably there will be induced changes in foreign GDPs, which will further affect these countries' imports and exports. The repercussions of these induced changes in output and trade will then presumably affect the development of China's output and trade. But these second-round effects will be small relative to the first-order effects that we add to previous analyses.

${ }^{24}$ Substituting the parameters for the shorter (post-1996) period only reinforces our results (see below).

${ }^{25}$ Given the multicolinearity problem described above, we regard these constrained estimates as more reliable.
} 
Table 8 shows the results. We report the percentage change in exports of capital goods, intermediates and consumer goods in the first three columns and the sum of the three effects - weighted by the country-specific share of each type of exports - for each Asian country. The numbers in each column are the sum of the direct effect of Chinese growth on China's demand for imports and the indirect effect, if any, in crowding out exports in third markets. For example, a 10 per cent increase in Chinese income leads to a 0.3 per cent increase in Japanese exports. Since the crowding out coefficients in the equations for capital goods and intermediates are small and insignificant, we set them to zero in these simulations. $^{26}$

Table 8 shows a range of effects, both in terms of the sign of the change in exports and its magnitude. ${ }^{27}$ But there is a pattern to those effects. China's growth has a positive effect on the exports of high income Asian countries such as Japan, Singapore and South Korea that are significant exporters of capital goods, little discernible effect on the exports of middle income countries such as Malaysia and the Philippines that export a range of products, and a strong negative effect on the exports of low-income Asian countries such as Bangladesh, Sri Lanka, Pakistan and Vietnam that are heavily dependent on the production and sale of consumer goods. This reflects the greater tendency for Chinese exports to compete with other countries' exports of consumer

\footnotetext{
${ }^{26}$ Using the actual values of these insignificant coefficients (rather than setting them to zero) only strengthens the key result of this section, that the exports of high-income countries specialized in the production of capital goods rise with Chinese GDP, while the exports of low-income countries specialized in the production of consumer goods fall with Chinese incomes. This is because the sign of the insignificant coefficient in the equation for capital goods is positive.

${ }^{27}$ When we add the vector of interaction terms for individual Asian exporters to the trade equations, we get negative effects of Chinese income growth on the neighbors, across the board. The reason why will be evident from Table 4, where one sees that every element of the vector tends to enter with a negative sign. These negative effects of Chinese export growth in third markets then dominate the direct effect on Chinese import demand. However, the coefficient estimates in question suffer from multicolinearity, as explained above. Hence we are not inclined to place too much weight on those results.
} 
goods, together with the country's unusually high income elasticity of demand for capital-goods imports - and the different product mixes of different countries.

A number of additional country-specific results are worth flagging. First, of all the Asian countries considered, South Korea enjoys the largest percentage increase in exports, mainly reflecting the stimulus felt by its capital-goods producers. ${ }^{28}$ Second, Indonesia experiences only a small negative overall effect despite a significant fall in consumer-goods exports, reflecting its dependence on commodity exports, including energy. ${ }^{29}$ Third, the net impact on India is smaller than that on Bangladesh, Pakistan, and Sri Lanka, reflecting its more diversified product mix. All of these results are consistent with common sense and conventional wisdom.

\section{Conclusions and Implications}

In this paper we have analyzed the impact of China's growth on the exports of its Asian neighbors. Our innovation has been to distinguish the increase in China's own demand for imports from the effects of its increased penetration of export markets, and the tendency for the latter to crowd out the exports of its Asian neighbors. Use of the gravity model has enabled us to disaggregate among commodity types and to adjust for the endogeneity of Chinese exports.

\footnotetext{
${ }^{28} 40$ per cent of Korea's exports are capital goods, a lower share than Japan's 52 per cent and Singapore's 60 per cent. However, 10 per cent of Korea's capital goods exports go to China, which is the highest among all Asian exporting countries. Similarly, while a third of Korea's exports are consumer goods, putting it roughly in the middle among Asian countries, nearly a tenth of those consumer goods exports go to China, which is the highest share among Asian countries. Thus, both factors help to account why

Korea's exports suffer least from Chinese income growth.

${ }^{29}$ Energy is included with intermediates in our calculations. Thus, for Indonesia the positive response of exports of intermediates to China essentially offset the negative effect on Indonesian exports of consumer goods to third markets.
} 
We find different effects for exporters of capital goods and consumer goods and hence for Asia's more and less developed countries. There is a tendency for China's exports to third markets to crowd out the exports of other Asian countries. But this effect is felt mainly in markets for consumer goods and hence by less-developed Asian countries that export those products, not in markets for capital goods or by the more advanced Asian economies for which machinery and equipment comprise a significant fraction of total exports. This makes sense, in that it has been markets for generic consumer goods and not those for technologically sophisticated machinery and equipment that have been first to be penetrated by Chinese exporters. At the same time, there has been a strong tendency for a rapidly growing China to suck up imports from its Asian neighbors, offsetting the third-market effect to a greater or lesser extent. But this direct effect of Chinese imports is mainly felt in markets for capital goods, where China's income elasticity of import demand is highest, and thus by the more advanced Asian economies. Hence, more and less developed Asian countries are being affected very differently by China's rise. Our benchmark results suggest that an increase in Chinese output, and thus in both China's appetite for imports and capacity to export, positively affects the exports of its high-income neighbors but negative affects the exports of lessdeveloped countries in the region.

These results are not reassuring for those concerned with the plight of Asia's poorer countries. Of course, trade is only one channel through which China is affecting its Asian neighbors. An example of another channel is foreign direct investment (FDI). The issues that arise in this context are analogous to those analyzed here. On the one hand there is FDI diversion, or the tendency for China as an FDI magnet to appropriate 
foreign investment previously destined for other Asian countries. On the other hand there are the benefits of Asian countries' own foreign direct investment in China, which presumably means a higher marginal rate of return on investment than would be available otherwise to domestic firms and households. As in our analysis, the overall impact depends on the relative magnitude the two effects, which is uncertain in theory and can only be determined empirically. But some previous discussions of FDI diversion suggest, analogously to our results for trade, that Asia's less developed countries that seek to compete with China on the basis of labor costs are particularly exposed to the danger of FDI diversion.

The past is also an imperfect guide to the future. Our results suggest that China's elasticity of demand for imports from its Asian neighbors has been shifting up over time. If this trend continues, it could be that the direct positive impact of China's demand for imports will soon dominate the third-market crowding-out effects of its exports for a growing number of Asian countries. The fact that China's trade balance has recently swung from surplus to deficit, evidently as a corollary of its continuing economic growth, is consistent with this more sanguine view. Be that as it may, we will have to wait for more data before we know whether this outcome in fact obtains. 


\section{References}

Ahearne, Alan G., John G. Fernald, Prakash Loungani and John W. Schindler (2003), “China and Emerging Asia: Comrades or Competitors?" International Finance Discussion Paper no. 789, Board of Governors, Federal Reserve System (December).

Anderson, James and Douglas Marcouiller (2002), "Insecurity and the Pattern of Trade: An Empirical Investigation," Review of Economics and Statistics 84, pp.342-352.

Eichengreen, Barry and Douglas Irwin (1995), "Trade Blocs, Currency Blocs, and the Reorientation of Trade in the 1930s," Journal of International Economics 38, pp.1-24..

Ianchovichina, Elena and Terrie Walmsley (2003), "Impact of China's WTO Accession on East Asia," unpublished manuscript, the World Bank.

International Monetary Fund (2004), "China's Emergence and its Impact on the Global Economy," World Economic Outlook (April).

Mayer, Jorg (2003), "The Fallacy of Composition: A Review of the Literature," UNCTAD Discussion Paper no. 166 (February).

Rose, Andrew (2002), "Do We Really Know that the WTO Increases Trade?" American Economic Review 94, pp. 98-114.

Yang, Tongzheng and David Vines (2000), "The Fallacy of Composition and the Terms of Trade of Newly Industrializing Economies," unpublished manuscript, Oxford University. 


\begin{tabular}{|c|c|c|c|}
\hline & $\begin{array}{c}\text { Full } \\
\text { Instrument set }\end{array}$ & $\begin{array}{c}\text { Limited } \\
\text { Instrument set }\end{array}$ & OLS \\
\hline China's exports (log) & $\begin{array}{l}-0.18 \\
(0.02)\end{array}$ & $\begin{array}{l}-0.23 \\
(0.03)\end{array}$ & $\begin{array}{c}0.37 \\
(0.01)\end{array}$ \\
\hline GDP of importing country (log) & $\begin{array}{c}1.02 \\
(0.03)\end{array}$ & $\begin{array}{c}1.03 \\
(0.03)\end{array}$ & $\begin{array}{c}0.49 \\
(0.01)\end{array}$ \\
\hline GDP per capita of importing country (log) & $\begin{array}{c}0.16 \\
(0.01)\end{array}$ & $\begin{array}{c}0.14 \\
(0.01)\end{array}$ & $\begin{array}{c}0.14 \\
(0.01)\end{array}$ \\
\hline GDP of exporting country (log) & $\begin{array}{c}0.73 \\
(0.01)\end{array}$ & $\begin{array}{c}0.70 \\
(0.01)\end{array}$ & $\begin{array}{c}0.70 \\
(0.01)\end{array}$ \\
\hline GDP per capita of exporting country (log) & $\begin{array}{c}0.40 \\
(0.01)\end{array}$ & $\begin{array}{c}0.45 \\
(0.01)\end{array}$ & $\begin{array}{l}0.40 \\
(0.1)\end{array}$ \\
\hline Product of land areas (log) & $\begin{array}{l}-0.03 \\
(0.01)\end{array}$ & $\begin{array}{l}-0.03 \\
(0.01)\end{array}$ & $\begin{array}{l}-0.01 \\
(0.01)\end{array}$ \\
\hline$\overline{\text { Distance (log) }}$ & $\begin{array}{l}-1.41 \\
(0.03)\end{array}$ & $\begin{array}{l}-1.68 \\
(0.04) \\
\end{array}$ & $\begin{array}{l}-0.94 \\
(0.02) \\
\end{array}$ \\
\hline Common language dummy & $\begin{array}{c}0.51 \\
(0.03) \\
\end{array}$ & $\begin{array}{c}0.50 \\
(0.03) \\
\end{array}$ & $\begin{array}{c}0.36 \\
(0.03) \\
\end{array}$ \\
\hline Number of land locked (0/1/2) & $\begin{array}{l}-1.00 \\
(0.03) \\
\end{array}$ & $\begin{array}{l}-0.90 \\
(0.03) \\
\end{array}$ & $\begin{array}{l}-0.76 \\
(0.03) \\
\end{array}$ \\
\hline Number of islands $(0 / 1 / 2)$ & $\begin{array}{l}-0.43 \\
(0.02) \\
\end{array}$ & $\begin{array}{l}-0.34 \\
(0.02) \\
\end{array}$ & $\begin{array}{l}-0.36 \\
(0.02) \\
\end{array}$ \\
\hline Land border dummy & $\begin{array}{c}0.19 \\
(0.12) \\
\end{array}$ & $\begin{array}{l}-0.35 \\
(0.11) \\
\end{array}$ & $\begin{array}{c}0.73 \\
(0.10) \\
\end{array}$ \\
\hline Common colonizer post 1945 & $\begin{array}{c}0.95 \\
(0.04) \\
\end{array}$ & $\begin{array}{c}0.91 \\
(0.04) \\
\end{array}$ & $\begin{array}{c}0.82 \\
(0.04) \\
\end{array}$ \\
\hline Dummy for pairs ever in colonial relationship & $\begin{array}{c}1.05 \\
(0.13) \\
\end{array}$ & $\begin{array}{c}1.20 \\
(0.11) \\
\end{array}$ & $\begin{array}{c}1.12 \\
(0.12) \\
\end{array}$ \\
\hline Constant & $\begin{array}{l}-31.28 \\
(0.45)\end{array}$ & $\begin{array}{l}-28.94 \\
(0.44) \\
\end{array}$ & $\begin{array}{l}-24.7 \\
(0.33)\end{array}$ \\
\hline Number of Observations & 18354 & 18354 & 18379 \\
\hline R-squared & 0.73 & 0.70 & 0.78 \\
\hline
\end{tabular}

Note: Standard errors in parentheses. 


\begin{tabular}{|c|c|c|}
\hline \multicolumn{3}{|c|}{$\begin{array}{l}\text { Table 1b: First Stage Estimation: Determinants of China's } \\
\text { Exports to Third Markets }\end{array}$} \\
\hline & $\begin{array}{c}\text { Full } \\
\text { Instrument set }\end{array}$ & $\begin{array}{c}\text { Limited } \\
\text { Instrument set }\end{array}$ \\
\hline$\overline{\text { GDP of importing country (log) }}$ & $\begin{array}{c}0.91 \\
(0.01)\end{array}$ & $\begin{array}{c}0.92 \\
(0.01)\end{array}$ \\
\hline GDP per capita of importing country (log) & $\begin{array}{c}0.06 \\
(0.01)\end{array}$ & $\begin{array}{c}0.05 \\
(0.01)\end{array}$ \\
\hline$\overline{\text { GDP of exporting country (log) }}$ & $\begin{array}{c}0.02 \\
(0.01)\end{array}$ & $\begin{array}{c}0.05 \\
(0.01)\end{array}$ \\
\hline GDP per capita of exporting country (log) & $\begin{array}{l}-0.01 \\
(0.01)\end{array}$ & $\begin{array}{l}-0.03 \\
(0.01)\end{array}$ \\
\hline Product of land areas (log) & $\begin{array}{l}-0.02 \\
(0.01) \\
\end{array}$ & $\begin{array}{l}-0.03 \\
(0.01)\end{array}$ \\
\hline$\overline{\text { Distance }(\log )}$ & $\begin{array}{l}-0.13 \\
(0.03)\end{array}$ & $\begin{array}{l}-0.13 \\
(0.03)\end{array}$ \\
\hline Common language dummy & $\begin{array}{c}0.32 \\
(0.02)\end{array}$ & $\begin{array}{c}0.28 \\
(0.02)\end{array}$ \\
\hline Number of land locked (0/1/2) & $\begin{array}{l}-0.60 \\
(0.02)\end{array}$ & $\begin{array}{l}-0.53 \\
(0.02)\end{array}$ \\
\hline Number of islands $(0 / 1 / 2)$ & $\begin{array}{l}-0.07 \\
(0.02) \\
\end{array}$ & $\begin{array}{l}-0.10 \\
(0.02) \\
\end{array}$ \\
\hline Land border dummy & $\begin{array}{c}-0.37 \\
(0.09)\end{array}$ & $\begin{array}{c}-0.38 \\
(0.09)\end{array}$ \\
\hline Common colonizer post 1945 & $\begin{array}{c}0.32 \\
(0.03)\end{array}$ & $\begin{array}{c}0.32 \\
(0.03)\end{array}$ \\
\hline Dummy for pairs ever in colonial relation & $\begin{array}{c}-0.06 \\
(0.10)\end{array}$ & $\begin{array}{c}-0.10 \\
(0.10)\end{array}$ \\
\hline Distance from China to third market (log) & $\begin{array}{c}-0.91 \\
(0.03)\end{array}$ & $\begin{array}{c}-0.91 \\
(0.03)\end{array}$ \\
\hline$\overline{\text { China's GDP (log) }}$ & $\begin{array}{c}1.14 \\
(0.02)\end{array}$ & \\
\hline Constant & $\begin{array}{c}-40.0 \\
(0.70) \\
\end{array}$ & $\begin{array}{c}-9.56 \\
(0.27) \\
\end{array}$ \\
\hline Number of observations & 18354 & 18354 \\
\hline R-square & 0.82 & 0.80 \\
\hline Note: Standard errors in parentheses. & & \\
\hline
\end{tabular}


Table 2: Impact of China's Exports on Asian Countries' Exports to Third Markets, Recent Period (1997-2002)

\begin{tabular}{lcc}
\hline & Coefficient & Standard error \\
\hline China's exports (log) & -0.33 & 0.05 \\
\hline GDP of importing country (log) & 1.17 & 0.05 \\
\hline GDP per capita of importing country (log) & 0.15 & 0.02 \\
\hline GDP of exporting country (log) & 0.76 & 0.02 \\
\hline GDP per capita of exporting country (log) & 0.33 & 0.02 \\
\hline Product of land areas (log) & -0.04 & 0.01 \\
\hline Distance (log) & -1.29 & 0.04 \\
\hline Common language dummy & 0.51 & 0.05 \\
\hline Number of land locked (0/1/2) & -1.09 & 0.05 \\
\hline Number of islands (0/1/2) & -0.50 & 0.03 \\
\hline Land border dummy & 0.34 & 0.17 \\
\hline Common colonizer post 1945 & 0.95 & 0.06 \\
\hline Dummy for pairs ever in colonial relationship & 0.93 & 0.19 \\
\hline Constant & -35.39 & 0.86 \\
\hline Number of Observations & 9444 & \\
\hline R-squared & 0.72 & \\
\hline
\end{tabular}


Table 3a: The Impact of China's Exports on Asian Countries' Exports to Third Markets (1990-2002), with the Addition of Time-Varying Instruments

\begin{tabular}{lcccc}
\hline & Full IV & Full IV & Limited IV & Limited IV \\
\hline China's exports (log) & coef. & st. err. & coef. & st. err. \\
\hline GDP of importing country (log) & -0.157 & 0.026 & -0.054 & 0.040 \\
\hline GDP per capita of importing country (log) & 0.970 & 0.026 & 0.876 & 0.038 \\
\hline GDP of exporting country (log) & 0.133 & 0.015 & 0.141 & 0.015 \\
\hline GDP per capita of exporting country (log) & 0.662 & 0.014 & 0.652 & 0.013 \\
\hline Product of land areas (log) & 0.408 & 0.017 & 0.421 & 0.017 \\
\hline Distance (log) & 0.000 & 0.007 & 0.007 & 0.007 \\
\hline Common language dummy & -1.484 & 0.034 & -1.385 & 0.044 \\
\hline Number of land locked (0/1/2) & 0.490 & 0.033 & 0.463 & 0.033 \\
\hline Number of islands (0/1/2) & -0.749 & 0.037 & -0.711 & 0.038 \\
\hline Land border dummy & -0.481 & 0.024 & -0.472 & 0.023 \\
\hline Common colonizer post 1945 & -0.544 & 0.132 & -0.431 & 0.132 \\
\hline Dummy for pairs ever in colonial relationship & 0.870 & 0.044 & 0.849 & 0.043 \\
\hline Political Risk for importing country & 1.088 & 0.124 & 1.097 & 0.120 \\
\hline Political Risk for exporting country & 0.010 & 0.001 & 0.008 & 0.002 \\
\hline Constant & 0.008 & 0.001 & 0.006 & 0.001 \\
\hline Number of Obs & -29.7 & 0.5 & -28.6 & 0.6 \\
\hline R^2 & 14399 & & 14399 & \\
\hline
\end{tabular}


Table 3b: First Stage Estimation: Determinants of China's Exports to Third Markets

\begin{tabular}{lcccc}
\hline & Full IV & Full IV & Limited IV & Limited IV \\
\hline & coef. & st. err. & coef. & st. err. \\
\hline GDP of importing country (log) & 0.857 & 0.008 & 0.877 & 0.008 \\
\hline GDP per capita of importing country (log) & 0.041 & 0.012 & -0.069 & 0.012 \\
\hline GDP of exporting country (log) & 0.043 & 0.010 & 0.087 & 0.010 \\
\hline GDP per capita of exporting country (log) & -0.027 & 0.013 & -0.135 & 0.013 \\
\hline Product of land areas (log) & -0.029 & 0.005 & -0.044 & 0.006 \\
\hline Distance (log) & -0.151 & 0.031 & -0.145 & 0.032 \\
\hline Common language dummy & 0.345 & 0.024 & 0.276 & 0.026 \\
\hline Number of land locked (0/1/2) & -0.404 & 0.027 & -0.420 & 0.028 \\
\hline Number of islands (0/1/2) & -0.066 & 0.018 & -0.081 & 0.019 \\
\hline Land border dummy & -0.543 & 0.097 & -0.561 & 0.103 \\
\hline Common colonizer post 1945 & 0.308 & 0.032 & 0.322 & 0.034 \\
\hline Dummy for pairs ever in colonial relation & -0.020 & 0.092 & -0.078 & 0.097 \\
\hline Political Risk for importing country & 0.008 & 0.001 & 0.023 & 0.001 \\
\hline Political Risk for exporting country & -0.002 & 0.001 & 0.011 & 0.001 \\
\hline Distance from China to third market (log) & -1.001 & 0.031 & -0.993 & 0.033 \\
\hline China's GDP (log) & 1.187 & 0.030 & & \\
\hline China's Risk & -0.001 & 0.002 & 0.008 & 0.002 \\
\hline Cons & -39.8 & 0.8 & -9.2 & 0.3 \\
\hline Number of Obs & 14399 & & 14399 & \\
\hline R^2 & 0.82 & & 0.8 & \\
\hline & & & & \\
\hline
\end{tabular}




\begin{tabular}{|c|c|c|c|c|c|c|c|c|}
\hline \multicolumn{9}{|c|}{$\begin{array}{c}\text { Table 4: The Impact of China's Exports on Asian Countries' Exports to Third Markets, } \\
\text { Disaggregated by Class of Importing and Exporting Country }\end{array}$} \\
\hline & $\begin{array}{l}\text { Industrial } \\
\text { (coef.) }\end{array}$ & $\begin{array}{l}\text { Industrial } \\
\text { (st. err.) }\end{array}$ & $\begin{array}{l}\text { Developing } \\
\text { (coef.) }\end{array}$ & $\begin{array}{l}\text { Developing } \\
\text { (st. err.) }\end{array}$ & $\begin{array}{c}\text { Asian } \\
\text { exporters } \\
\text { (coef.) }\end{array}$ & $\begin{array}{l}\text { Asian } \\
\text { exporters } \\
\text { (st. err.) }\end{array}$ & $\begin{array}{c}\text { Asian \& } \\
\text { Industrial } \\
\text { (coef.) }\end{array}$ & $\begin{array}{c}\text { Asian \& } \\
\text { Industrial } \\
\text { (st. err.) }\end{array}$ \\
\hline China's exports (log) & -0.204 & 0.058 & -0.137 & 0.028 & & & & \\
\hline GDP of importing country (log) & 1.234 & 0.063 & 0.876 & 0.028 & 1.156 & 0.025 & 1.141 & 0.025 \\
\hline GDP per capita of importing & -0.080 & 0.053 & 0.160 & 0.019 & 0.057 & 0.015 & 0.027 & 0.015 \\
\hline GDP of exporting country (log) & 0.463 & 0.017 & 0.732 & 0.017 & 0.925 & 0.023 & 0.886 & 0.024 \\
\hline GDP per capita of exporting & 0.388 & 0.021 & 0.405 & 0.021 & 0.205 & 0.025 & 0.139 & 0.026 \\
\hline Product of land areas (log) & 0.090 & 0.009 & -0.031 & 0.010 & -0.064 & 0.008 & -0.073 & 0.008 \\
\hline Distance (log) & -0.356 & 0.048 & -1.630 & 0.040 & -1.648 & 0.033 & -1.676 & 0.032 \\
\hline Common language dummy & 0.519 & 0.042 & 0.346 & 0.041 & 0.615 & 0.034 & 0.593 & 0.033 \\
\hline Number of land locked (0/1/2) & -0.535 & 0.059 & -0.756 & 0.044 & -0.766 & 0.034 & -0.779 & 0.033 \\
\hline Number of islands $(0 / 1 / 2)$ & -0.093 & 0.030 & -0.641 & 0.031 & -0.360 & 0.031 & -0.305 & 0.031 \\
\hline Land border dummy & & & -0.631 & 0.140 & -0.827 & 0.121 & -0.817 & 0.119 \\
\hline Common colonizer post 1945 & & & 0.847 & 0.047 & 0.722 & 0.042 & 0.683 & 0.043 \\
\hline Dummy for pairs ever in colonial & 0.692 & 0.086 & 0.284 & 0.290 & 0.963 & 0.113 & 0.934 & 0.112 \\
\hline Political Risk for importing country & 0.018 & 0.003 & 0.009 & 0.002 & 0.014 & 0.001 & 0.012 & 0.001 \\
\hline Political Risk for exporting country & 0.013 & 0.002 & 0.006 & 0.002 & 0.006 & 0.001 & 0.009 & 0.001 \\
\hline Fitimchina*Japan & & & & & -0.427 & 0.029 & -0.360 & 0.030 \\
\hline Fitimchina*Bangladesh & & & & & -0.458 & 0.026 & -0.575 & 0.027 \\
\hline Fitimchina*Sri Lanka & & & & & -0.235 & 0.025 & -0.284 & 0.026 \\
\hline Fitimchina*India & & & & & -0.340 & 0.028 & -0.316 & 0.029 \\
\hline Fitimchina*Indonesia & & & & & -0.162 & 0.025 & -0.115 & 0.025 \\
\hline Fitimchina*Korea & & & & & -0.330 & 0.027 & -0.231 & 0.028 \\
\hline Fitimchina*Malaysia & & & & & -0.155 & 0.026 & -0.139 & 0.026 \\
\hline Fitimchina*Pakistan & & & & & -0.381 & 0.026 & -0.398 & 0.026 \\
\hline Fitimchina*Philippines & & & & & -0.348 & 0.025 & -0.431 & 0.026 \\
\hline Fitimchina*Singapore & & & & & -0.237 & 0.028 & -0.214 & 0.029 \\
\hline Fitimchina*Thailand & & & & & -0.268 & 0.026 & -0.263 & 0.027 \\
\hline Fitimchina*Vietnam & & & & & -0.235 & 0.027 & -0.276 & 0.028 \\
\hline Fitimchina*Japan*Industrial & & & & & & & -0.004 & 0.015 \\
\hline Fitimchina*Bangladesh*Industrial & & & & & & & 0.245 & 0.015 \\
\hline Fitimchina*Sri Lanka*Industrial & & & & & & & 0.088 & 0.015 \\
\hline Fitimchina*India*Industrial & & & & & & & -0.021 & 0.015 \\
\hline Fitimchina*Indonesia*Industrial & & & & & & & -0.055 & 0.015 \\
\hline Fitimchina*Korea*Industrial & & & & & & & -0.132 & 0.014 \\
\hline Fitimchina*Malaysia*Industrial & & & & & & & 0.016 & 0.015 \\
\hline 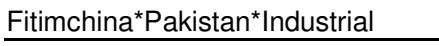 & & & & & & & 0.057 & 0.014 \\
\hline Fitimchina*Philippines*Industrial & & & & & & & 0.196 & 0.015 \\
\hline Fitimchina*Singapore*Industrial & & & & & & & -0.005 & 0.015 \\
\hline Fitimchina*Thailand ${ }^{*}$ Industrial & & & & & & & 0.042 & 0.014 \\
\hline Fitimchina ${ }^{*}$ Vietnam*Industrial & & & & & & & 0.061 & 0.015 \\
\hline Constant & -42.0 & 1.7 & -27.2 & 0.5 & -35.3 & 0.6 & -32.9 & 0.7 \\
\hline Number of observations & 3375 & & 11024 & & 14399 & & 14399 & \\
\hline R-square & 0.88 & & 0.74 & & 0.81 & & 0.82 & \\
\hline
\end{tabular}




\begin{tabular}{|c|c|c|c|c|c|c|}
\hline \multicolumn{7}{|c|}{$\begin{array}{l}\text { Table 5: The Impact of China's Exports on Asian Countries' Exports to Third Markets } \\
(\mathbf{1 9 9 0 - 2 0 0 2 )}\end{array}$} \\
\hline & $\begin{array}{l}\text { Capital } \\
\text { Goods }\end{array}$ & $\begin{array}{l}\text { Capital } \\
\text { Goods }\end{array}$ & $\begin{array}{c}\text { Consumer } \\
\text { Goods }\end{array}$ & $\begin{array}{c}\text { Consumer } \\
\text { Goods }\end{array}$ & $\begin{array}{c}\text { Inter- } \\
\text { mediates }\end{array}$ & $\begin{array}{c}\text { Inter- } \\
\text { mediates }\end{array}$ \\
\hline & Coef. & St. err. & Coef. & St. err. & Coef. & St. err. \\
\hline China's exports (log) & 0.02 & 0.03 & -0.284 & 0.035 & -0.014 & 0.038 \\
\hline GDP of importing country (log) & 0.86 & 0.03 & 1.027 & 0.033 & 1.058 & 0.042 \\
\hline GDP per capita of importing country (log) & 0.13 & 0.03 & 0.279 & 0.020 & -0.092 & 0.024 \\
\hline GDP of exporting country (log) & 0.84 & 0.02 & 0.693 & 0.017 & 0.774 & 0.018 \\
\hline GDP per capita of exporting country (log) & 0.88 & 0.03 & 0.202 & 0.021 & 0.434 & 0.023 \\
\hline Product of land areas (log) & 0.03 & 0.01 & 0.018 & 0.009 & 0.010 & 0.010 \\
\hline Distance $(\log )$ & -1.25 & 0.05 & -1.448 & 0.043 & -1.496 & 0.050 \\
\hline Common language dummy & 0.72 & 0.05 & 0.466 & 0.042 & 0.317 & 0.045 \\
\hline Number of land locked $(0 / 1 / 2)$ & -0.30 & 0.06 & -0.436 & 0.045 & -0.682 & 0.051 \\
\hline Number of islands $(0 / 1 / 2)$ & -0.20 & 0.04 & -0.443 & 0.029 & -0.427 & 0.031 \\
\hline Land border dummy & 0.10 & 0.20 & -1.199 & 0.166 & -0.324 & 0.174 \\
\hline Common colonizer post 1945 & 0.99 & 0.07 & 0.785 & 0.057 & 1.272 & 0.062 \\
\hline Dummy for pairs ever in colonial relationship & 1.515 & 0.18 & 1.271 & 0.142 & 0.999 & 0.152 \\
\hline Political Risk for importing country & 0.010 & 0.002 & 0.018 & 0.002 & 0.003 & 0.002 \\
\hline Political Risk for exporting country & 0.029 & 0.002 & 0.008 & 0.002 & 0.002 & 0.002 \\
\hline Constant & -29.557 & 0.636 & -15.557 & 0.482 & -21.042 & 0.522 \\
\hline Number of Obs. & 10702 & & 12040 & & 11783 & \\
\hline $\mathrm{R}^{\wedge} 2$ & 0.730 & & 0.7 & & 0.73 & \\
\hline
\end{tabular}




\begin{tabular}{|c|c|c|c|c|}
\hline \multicolumn{5}{|c|}{$\begin{array}{c}\text { Table 6: China's Imports from Asian Countries, } \\
\text { Disaggregated by Exporting Country }\end{array}$} \\
\hline & 1990-2002 & 1990-2002 & 1997-2002 & $1997-2002$ \\
\hline & Coefficient & St. Error & Coefficient & St. Error \\
\hline Log of China's GDP*Japan & 0.95 & 0.40 & 2.28 & 0.81 \\
\hline Log of China's GDP*Korea & 1.05 & 0.35 & 2.18 & 0.71 \\
\hline Log of China's GDP*Singapore & 0.97 & 0.32 & 2.03 & 0.56 \\
\hline Log of China's GDP*Indonesia & 1.22 & 0.35 & 2.14 & 0.81 \\
\hline Log of China's GDP*Malaysia & 1.11 & 0.31 & 2.07 & 0.64 \\
\hline Log of China's GDP*Philippines & 1.16 & 0.32 & 2.05 & 0.72 \\
\hline Log of China's GDP*Thailand & 1.12 & 0.33 & 2.10 & 0.71 \\
\hline Log of China's GDP*Bangladesh & 1.16 & 0.32 & 1.92 & 0.76 \\
\hline Log of China's GDP*Cambodia & 1.16 & 0.26 & 1.82 & 0.56 \\
\hline Log of China's GDP*Sri Lanka & 1.05 & 0.28 & 1.80 & 0.60 \\
\hline Log of China's GDP* Pakistan & 1.21 & 0.33 & 2.03 & 0.76 \\
\hline Log of China's GDP* Vietnam & 1.25 & 0.31 & 2.01 & 0.71 \\
\hline Log of China's GDP*India & 1.23 & 0.40 & 2.16 & 0.95 \\
\hline Log of GDP of exporting country & 0.34 & 1.26 & -1.34 & 2.84 \\
\hline Log of GDP per capita of exporting country & 2.29 & 1.52 & 0.76 & 3.04 \\
\hline Constant & -50.56 & 18.25 & -21.90 & 35.80 \\
\hline Number of Observations & 166 & & 78 & \\
\hline R-squared & 0.95 & & 0.98 & \\
\hline
\end{tabular}




\begin{tabular}{lccc}
\hline \multicolumn{4}{c}{$\begin{array}{c}\text { Table 7: China's Imports from Asian Countries, } \\
\text { Disaggregated by Commodity Type } \\
(\mathbf{1 9 9 0 - 2 0 0 2 )}\end{array}$} \\
\hline $\begin{array}{l}\text { Capital } \\
\text { Goods }\end{array}$ & $\begin{array}{c}\text { Consumer } \\
\text { Goods }\end{array}$ & $\begin{array}{c}\text { Inter- } \\
\text { mediates }\end{array}$ \\
\hline Japan & 2.16 & 1.35 & 0.40 \\
\hline Bangladesh & 1.61 & 1.39 & 0.92 \\
\hline Sri lanka & 2.12 & 1.40 & 0.51 \\
\hline India & 1.44 & 1.43 & 1.24 \\
\hline Indonesia & 1.83 & 1.44 & 0.98 \\
\hline Korea & 2.27 & 1.44 & 0.48 \\
\hline Malaysia & 2.34 & 1.44 & 0.50 \\
\hline Pakistan & 1.72 & 1.50 & 0.91 \\
\hline Philippine & 2.02 & 1.43 & 0.77 \\
\hline Singapore & 2.74 & 1.41 & 0.05 \\
\hline Thailand & 2.12 & 1.46 & 0.67 \\
\hline Vietnam & 1.88 & 1.50 & 0.96 \\
\hline
\end{tabular}




\begin{tabular}{|c|c|c|c|c|}
\hline \multicolumn{5}{|c|}{ Table 8: Net Impact of China's Income Growth } \\
\hline & $\begin{array}{l}\text { Capital } \\
\text { Goods }\end{array}$ & $\begin{array}{c}\text { Consumer } \\
\text { Goods }\end{array}$ & $\begin{array}{c}\text { Inter- } \\
\text { mediates }\end{array}$ & Total \\
\hline Japan & 0.18 & -0.24 & 0.05 & 0.03 \\
\hline Bangladesh & 0.00 & -0.32 & 0.05 & -0.28 \\
\hline Cambodia & 0.01 & -0.32 & 0.09 & -0.24 \\
\hline Sri lanka & 0.03 & -0.32 & 0.00 & -0.25 \\
\hline India & 0.02 & -0.30 & 0.06 & -0.12 \\
\hline Indonesia & 0.14 & -0.30 & 0.08 & -0.04 \\
\hline Korea & 0.23 & -0.19 & 0.12 & 0.06 \\
\hline Malaysia & 0.11 & -0.30 & 0.04 & -0.01 \\
\hline Pakistan & 0.06 & -0.25 & 0.07 & -0.21 \\
\hline Philippine & 0.11 & -0.30 & 0.05 & -0.01 \\
\hline Singapore & 0.11 & -0.28 & 0.00 & 0.03 \\
\hline Thailand & 0.11 & -0.29 & 0.08 & -0.07 \\
\hline Vietnam & 0.04 & -0.30 & 0.14 & -0.14 \\
\hline
\end{tabular}

